Geosci. Model Dev. Discuss., https://doi.org/10.5194/gmd-2018-81

Manuscript under review for journal Geosci. Model Dev.

Discussion started: 6 June 2018

(c) Author(s) 2018. CC BY 4.0 License.

\title{
MOVEIM v1.0: Development of a bottom-up motor vehicular emission inventories for the urban area of Manaus in central Amazon rainforest.
}

\author{
Paulo Ricardo Teixeira ${ }^{1,3}$, Saulo Ribeiro de Freitas ${ }^{5}$, Francis Wagner Correia ${ }^{2}$, Antonio Ocimar Manzi ${ }^{4}$ \\ ${ }^{1}$ Post-graduate Program in Climate and Environment, CLIAMB, INPA/UEA, Av. André Araújo, Manaus, Amazonas, Brazil \\ $5{ }^{2}$ State University of Amazonas, Meteorology Department, Manaus, Amazonas, Brazil. \\ ${ }^{3}$ National Institute of Amazonian Research, Large-Scale Biosphere-Atmosphere Experiment in Amazonia, Manaus, Amazonas, \\ Brazil \\ ${ }^{4}$ National Institute of Space Research, Center for Weather Forecasting and Climate Research, Cachoeira Paulista, São Paulo, \\ Brazil \\ $10{ }^{5}$ Universities Space Research Association and NASA Goddard Space Flight Center, Greenbelt, MD, USA
}

Correspondence to: Paulo R. Teixeira (paulo.ricardo.teixeira@gmail.com), Saulo R. Freitas (saulo.r.freitas@nasa.gov) and Francis W. da Silva Correa (francis.wagner70@gmail.com).

\begin{abstract}
Emissions of gases and particulates in urban areas are associated with a mixture of various sources, both natural and anthropogenic. Understanding and quantifying these emissions is necessary in studies of climate change, local air pollution issues and weather modification. Studies have highlighted that the transport sector is key to closing the world's emissions gap. Vehicles contribute substantially with the emission of carbon dioxide $\left(\mathrm{CO}_{2}\right)$, carbon monoxide $(\mathrm{CO})$, nitrogen oxides $\left(\mathrm{NO}_{\mathrm{x}}\right)$, nonmethane hydrocarbon (NMHC), particulate matter (PM), methane $\left(\mathrm{CH}_{4}\right)$, hydrofluorocarbon (HFC) and nitrous oxide $\left(\mathrm{N}_{2} \mathrm{O}\right)$. Several studies show that vehicle emission inventories are an important approach to providing a baseline estimate of on-road emissions in several scales, mainly in urban areas. This approach is essential to areas with incomplete or non-existent monitoring networks as well as for air quality models. Conversely, the direct downscale of global emission inventories in chemical transport and air quality models may not be able to reproduce the observed evolution of atmospheric pollution processes at finer spatial scales. To address this caveat, we developed a bottom-up vehicular emission inventory along the 258 main traffic routes from Manaus, based on local vehicle fleet data and emission factors (EFs). The results show that the light vehicles are responsible for the largest fraction of the pollutants, contributing 2.6, 0.87, 0.32, 0.03, 456 and 0.8 ton/h of $\mathrm{CO}, \mathrm{NO}_{\mathrm{x}}, \mathrm{CH}_{4}, \mathrm{PM} \mathrm{CO}_{2}$ and
\end{abstract}

25 NMHC, respectively. Including the emissions of motorcycles, buses and trucks, our total estimation of the emissions is $4.1,1.0$, 0.37, $0.07,63.5$ and 2.56 ton/h, respectively. We also noted that light vehicles accounted for about $62.8 \%, 84.7 \%, 87.9 \%, 45.1 \%$, $71.8 \%$, and $33.9 \%$ and motorcycles in the order of $32.3 \%, 6.5 \%, 12.1 \%, 6.2 \%, 14.8 \%, 8.7 \%$, respectively. Nevertheless, we can highlight the bus emissions which are around $35.7 \%$ and $45.3 \%$ for NMHC and PM. Our results indicate a better distribution over the domain reflecting the influences of standard behavior of traffic distribution per vehicle category. Finally, this inventory

30 provides more detailed information to improving the current understanding of how vehicle emissions contribute to the ambient pollutant concentrations in Manaus and their impacts on regional climate changes. This work will also contribute to improved air quality numerical simulations, provide more accurate scenarios for policymakers and regulatory agencies to develop strategies for controlling the vehicular emissions, and, consequently, mitigate associated impacts on local and regional scales of the Amazon ecosystems.

35

Key words: Vehicle emission inventories, bottom-up approach, urban air pollution, Amazon forest 
Geosci. Model Dev. Discuss., https://doi.org/10.5194/gmd-2018-81

Manuscript under review for journal Geosci. Model Dev.

Discussion started: 6 June 2018

(c) Author(s) 2018. CC BY 4.0 License.

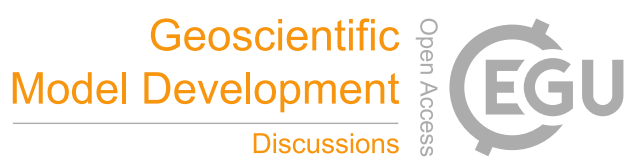

(c) (i)

\section{Introduction}

Since the pre-industrial era, the climate changes driven by anthropogenic emissions are one of the most pressing challenges faced by human development. Researchers have highlighted the effects of human activities on air quality, terrestrial ecosystems and global climate changes (Ramanathan et al. 2001; IPCC, 2014; Ashfold et al., 2015). The fast economic and population growth with a consequential increase in the number of vehicles has contributed significantly to the greenhouse gas (GHG) emissions and other and pollutants, therefore, affect the climate in global scale (Chapman, 2007; Stanley et al., 2011) besides bringing several adverse consequences on human health (Afroz et al., 2003; Abe et al., 2016; Scovronick et al., 2016; Yoshizaki et al., 2017). The GHG emissions associated with the transport sector have increased at a faster rate. Kahn et al. (2007) shown that in 2004, the transportation sector was responsible for $23 \%$ of the world's GHG emissions with about $75 \%$ coming from road vehicles. Recent studies suggested that of the atmospheric emissions the vehicle fleet is globally responsible for $30 \%$ of $\mathrm{NO}_{\mathrm{x}}, 25 \%$ of $\mathrm{PM} 2.5,54 \%$ of CO and 14\% of CO2 (Vasconcellos, 2006, Sokhi, 2011; Karangulian et al., 2015). Additionally, Sims et al (2014) shown that in 2010 the GHG emissions from the transport sector continued to increase at a faster rate more than any other sector with $7.0 \mathrm{Gt}$ $\mathrm{CO}_{2 \mathrm{eq}}$ this represents more than the doubled since $1970\left(2.9 \mathrm{Gt} \mathrm{CO}_{2 \mathrm{eq}}\right), 53 \%$ of these increase are from passenger modes and the

$5047 \%$ are freight mode, totaling $5 \mathrm{Gt} \mathrm{CO}_{2 \mathrm{eq}}$. The authors consider that more knowledge is needed about the worldwide potential for GHG emission reduction from the transport sector and that potential reduction is much more certain for passenger modes. During the United Nations Conference of Parties 21 (UN COP21) Climate Change Conference, it was highlighted that the transportation sector is key to closing the world's emissions gap (Ebinger et al., 2015). The world's emissions gap represents the difference between the emissions levels that countries have pledged to achieve under the Paris Agreement to combat climate change. The main goal is to hold the increase in the global average temperature to below $2.0^{\circ} \mathrm{C}$, compared to pre-industrial levels and consistent with the global effect of the Intended Nationally Determined Contributions (INDCs) (Rogelj et al., 2016; UNEP, 2017).

However, an air pollution monitoring network in many urban areas is either unavailable or inadequate. Alves et al (2014) suggested that in Brazil only $1.7 \%$ of the cities have an air pollution monitoring network, which represents 1.3 stations per 1

60 million inhabitants. These numbers are considerably lower than those in the U.S. (16 stations per 1 million inhabitants) and Europe (14.8 stations per 1 million inhabitants). Thus, vehicle emission inventories are a simple and needed approach that would provide a baseline estimate of on-road emissions on several scales. This information is essential to areas with incomplete or nonexistent monitoring networks (Nagpure and Gurjar, 2012) and to constrain pollutants surface fluxes for numerical air quality models (Coelho et al., 2014; Lozhkina and Lozhkin, 2015; Vara-Vela et al., 2016). As a means to minimize this gap in monitoring network, some studies suggested in general, two different approaches: top-down and bottom-up. The top-down approach uses values of annual emissions assessed at national levels; these emissions are spatially disaggregated at different levels by statistical indexes (e.g. population density, average number of trips, etc.). However, the 'bottom-up' approach is more accurate and uses data at local and municipal levels (e.g., locally measured emission factors, vehicular activity, fuel consumption, traffic characteristics, fleet characteristics, length of road, etc.). In several studies, both methods are utilized for

70 improving the accuracy of the emissions calculations applying a downscaling national emission, therefore disaggregating atmospheric emissions from the national scale to a city-scale (Kuenen et al., 2014; Janssens-Maenhout et al., 2015; Trombetti et al., 2017). In addition, Dios et al. (2012) suggest combining top-down and bottom-up methodologies for high-resolution inventories. However, despite efforts Zhou et al (2017) suggested that direct application of downscaled global emission inventories in chemical transport and air quality models, may not be a good solution to reproduce the real evolution of

75 atmospheric pollution processes at smaller spatial scales suggesting that the application of downscaling produces emission overestimates. 
Geosci. Model Dev. Discuss., https://doi.org/10.5194/gmd-2018-81

Manuscript under review for journal Geosci. Model Dev.

Discussion started: 6 June 2018

(c) Author(s) 2018. CC BY 4.0 License.

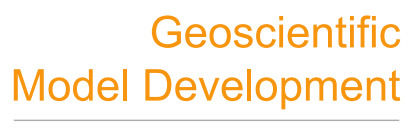

Discussions

(c) $\underset{\text { BY }}{\text { (i) }}$

Recent efforts have been made to develop vehicle emission inventories for several urban areas (Song et al., 2006; Bellasio et al., 2007; Jing et al., 2016; Andrade et al., 2010; Alonso et al., 2010; Venegas et al., 2011; Zhou et al., 2014). Particularly, a few years ago, in South America studies have reported information on vehicle emission inventories on a national scale or for specific cities. Gallardo et al. (2012) presented an evaluation of vehicle emission inventories for $\mathrm{CO}$ and $\mathrm{NO}_{\mathrm{x}}$ at Bogotá (Colombia), Buenos Aires (Argentina), Santiago (Chile) and São Paulo (Brazil). Puliafito et al. (2017), Puliafito et al. (2015), Venegas et al. (2011) have suggested a spatial disaggregated emission inventory in high resolution for Argentina. Alonso et al. (2010) developed an urban emissions inventory for South America based on the analysis and aggregation of local inventories of nine megacities, using socio-economic data of the region and correlation between vehicle density and mobile source emissions. This information was extrapolated geographically and distributed using a methodology that delimits urban areas using high-resolution satellite data and finally was integrated with worldwide emissions databases. In Brazil, several studies reported information on vehicle emission inventories in specifics cities such as Federal District (Réquia Júnior et al., 2015); Rio de Janeiro (Duarte et al., 2013); São Paulo (Andrade et al., 2004; Vivanco and Andrade, 2006; Martins et al., 2006; Gallardo et al., 2012); Campinas (Ueda and Tomaz, 2011). However, despite the efforts to implementer an air pollution monitoring network in national scale the

90 North, Northeast and Midwest regions of Brazil are characterized do not have emission-specific inventories at local and municipal levels.

In Brazil, in the North Region located in middle of the world's largest rainforest is the city of Manaus, which stands out for being a large urban area surrounded by primary tropical forests (Martin et al., 2016; Cecchini et al., 2016). Given such an environment, it is key to study the impact that Manaus has on atmospheric conditions. Studies have shown that the Amazon rainforest is sensitive to the variability and changes in the climate system due to both natural variations and anthropogenic actions, such as the increase in the concentration of GHG and aerosols in the atmosphere and changes in land use and land cover (LULC) (Fearnside et al., 2002; Artaxo et al., 2006; Betts et al., 2008; de Souza e Alvalá, 2014; Marengo e Espinoza, 2015). Previous studies of emissions have shown the effects of anthropogenic impact on the Amazon basin generally focused on biomass burning-related occasions (Artaxo et al., 2002; Roberts et al., 2003; Andreae et al., 2004; Freud et al., 2008; Martins and

100 Silva Dias, 2009; Artaxo et al., 2013). However, over the last years, several researchers have highlighted the effects of the Manaus plume pollution on the chemical properties of the local and remote atmosphere (Kuhn et al., 2010; Trebs et al., 2012; Rizzo et al., 2013; Bateman et al., 2017). During 2014-2015 the experiment Observations and Modeling of the Green Ocean Amazon (GoAmazon2014/5) was performed in the Manaus metropolitan area, the objective being to understand and quantify the impact of the pollution plume from the Manaus urban area on the complex interactions among vegetation, atmospheric

105 chemistry, and aerosol production as well as their connections to aerosols, clouds, and precipitation (Martin et al., 2016). As part of the GoAmazon2014/5 Experiment, the most recent results indicate that Manaus pollution plume impacts in the microphysical properties (e.g., smaller effective diameters and higher droplet number concentrations) of warm-phase clouds during wet season (e.g., Cecchini et al., 2016). In addition, de Sá et al. (2017) suggested that urban pollution is responsible for the increased emissions of nitrogen oxides and decreased particulate matter (PM) compared to background conditions at Amazon rainforest.

110 The authors indicate that this results corroborating with some futures scenarios of Amazonian economic development. In this context, the possible change of PM production would imply in alterations on air quality and regional climate.

Therefore, given such an environment it is key to quantify mobile sources emissions of Manaus city. Specifically, the purpose of this paper is to develop a vehicular emission inventory along the main traffic routes based on vehicle activity data and local emission factors using a bottom-up methodology. 
Geosci. Model Dev. Discuss., https://doi.org/10.5194/gmd-2018-81

Manuscript under review for journal Geosci. Model Dev.

Discussion started: 6 June 2018

(c) Author(s) 2018. CC BY 4.0 License.

(c) (i)

\section{Methodology and data}

\subsection{Brief description of the study area}

Manaus is situated at the confluence of the Negro and Solimões Rivers, more precisely between the parallels $2^{\circ} 55^{\prime} 00^{\prime \prime}$ and $3^{\circ} 10^{\prime} 00^{\prime \prime}$ south and the meridians 59 $52^{\prime} 30^{\prime \prime}$ and $60^{\circ} 07^{\prime} 30^{\prime \prime}$ west, occupying a total area of $377 \mathrm{~km}^{2}$ (Figure 1). With a population of more than 2 million is $7^{\text {th }}$ most populous city of Brazil (IBGE, 2015) being responsible for about $80 \%$ of the economic activity

120 of the state of Amazonas. With quick growth, with a rate average in the order of 7\% during 2010-2016, Manaus has seen the increase in the vehicle fleet as one of the major sources of air pollution. The motor vehicle census data from the National Transit Department (DENATRAN), show there were in 2010 around 453,000 vehicles registered in Manaus; today, it is estimated at $\sim 713,000$ vehicles (78.6\% of the vehicles of the state of Amazonas), meaning a 57.6\% increase. At an annual growth rate of 7\%, by 2020 the vehicle fleet could reach 1 million. The Manaus fleet is relatively young age and predominantly consisting by

125 flexible-fuel vehicles (blend between gasohol and hydrated ethanol); Medeiros et al. (2017) suggested an average age of 5 years attributed to the timing of rapid urban growth during the economic expansion between 2009 and 2015 .

Climatologically in the Manaus city the mean air temperature does not show strong seasonal variations due to the high incidence of solar radiation throughout the year. The highest temperatures are observed during the dry season, with a September monthly mean of $27.5^{\circ} \mathrm{C}$, whereas the lowest temperatures prevail in the rainy season, with a monthly mean of $25.9^{\circ} \mathrm{C}$ in March.

130 Rainfall in the region shows a pronounced seasonal variation, with the highest amounts in March (335.4 mm) and the lowest amounts in August (47.3 mm), with an average annual total of $2307.4 \mathrm{~mm}$ (Andreae et al. 2015). A typical characteristic for the central Amazon Basin is the synoptic changes between the wet and dry seasons; a good example of this is in the seasonal variations of the IntraTropical Convergence Zone (ITCZ) (Fisch et al., 1998; Wang and Fu 2007; Nobre et al., 2009). In the wet season, the Manaus plume aside, the Amazon basin is one of the cleanest continental regions on Earth (Andre ae, 2007; Martin et

135 al., 2010). In general, the preferential wind direction is from the Northeast (NE), featuring the occurrence of the breeze circulation in the same direction as the trade winds. Santos et al. (2014) observed that during the wet season, the trade winds flows more frequently from the Northeast (NE), while in the dry season they flow from the Southeast (SE). It has been suggested that these features are modulated by a land breeze circulation that is induced by the thermal gradient between Manaus City and the river water surfaces.

\section{$140 \quad 2.2$ General methodology description}

In this study, we applied a bottom-up approach to develop a vehicular emission inventory for the main anthropogenic emissions of an urban area: carbon monoxide $(\mathrm{CO})$, nitrogen oxide $\left(\mathrm{NO}_{\mathrm{x}}\right)$, methane $\left(\mathrm{CH}_{4}\right)$, particulate matter $(\mathrm{PM})$, carbon dioxide $\left(\mathrm{CO}_{2}\right)$ and non-methane hydrocarbon (NMHC). Thus, given a segment of road we established an hourly traffic profile for each vehicle category. Therefore, the emissions were calculated as follows in Eq. (1):

145

$E_{i, j}^{p}=\sum_{c} E F_{c}^{p} \times V T K_{c, i, j} \times 10^{-3}$

where $E_{i, j}^{p}$ is the emitted mass of a pollutant $p$ on a segment of road $i$ at time $j\left(\mathrm{~kg} \mathrm{~h}^{-1}\right) ; E F_{c}^{p}$ is the emission factor of pollutant $p$ by a vehicle category $c\left(\mathrm{~g} \mathrm{~km}^{-1}\right) ; V T K_{c, i, j}$ is distance travelled of a vehicle category $c$ on a segment of road $i$ at time $150 j\left(\mathrm{~km} \mathrm{~h}^{-1}\right)$. 
Geosci. Model Dev. Discuss., https://doi.org/10.5194/gmd-2018-81

Manuscript under review for journal Geosci. Model Dev.

Discussion started: 6 June 2018

(c) Author(s) 2018. CC BY 4.0 License.

Due to the significant differences among different vehicle classifications, the emission factors were separated by the vehicle category. However, it was not possible to determine the exact age and fuel type of vehicle on a segment of road $i$ at moment $j$. Thus, we used the existing classification method established by the Brazilian Ministry of Environment by which the vehicles have been summarized into 4 classes as follows: light vehicle - LV (e.g., passenger car, taxi); motorcycle; public transportation

155 bus, and heavy-duty truck - HDT (e.g., truck). The grouping intends to reflect the different fuels used and fleet-based functions for private and public transport or transport of goods.

The method to calculate VKT in a given time $j$ for a segment of road $i$ is to multiply the length of a road segment $\left(L_{i}\right)$ by the volume of traffic of category $c$ on that segment $i$ in a given time $j$, as shown by Eq. (2):

$160 V T K_{c, i, j}=V T_{c, i, j} \times L_{i}$

It is important to note that the VKT calculation does not include travel on all Manaus roads. Small residential streets are not used in the VKT calculation; the traffic volume varies or the traffic count sample on these roadways is too small or frequently inexistent to make a reliable estimation.

\subsection{Traffic flow, vehicle activity, vehicle density and emission factors}

The fleet composition, vehicle activity, density and traffic flow were obtained from three local sources: The Transit Department of the Amazonas (Detran-AM); the Municipal Institute of Engineering and Traffic Control of Manaus (MIETCM) and the Municipal Institute of Urban Planning. For the traffic volume, a database of the MIETCM was used, obtained by manually counting vehicles on the main roads over two time periods: morning rush hour (6-9 AM) and afternoon rush hour (5-7 PM). The

170 counting was done over several days at each road between the years 2014-2015. Thus, for every selected road, the vehicle flow was continuously counted in 15-minute intervals during these two-hour periods.

The accuracy of the emission factors (EFs) is key and impacts the results of the vehicle emissions inventories. International EFs are hard to match perfectly since they are directly related to the characteristics such as vehicle emission control level, fuel type, vehicle age, accumulated mileage, inspection and maintenance, average speed, fraction of cold/hot starts, etc. Some studies

175 have quantified EFs by employing tunnel measurements (Martins et al., 2006; Ban-Weiss et al., 2010) or the remote sensing approach (Bishop et al., 2010). Despite the efforts to improve EFs, both of these approaches have significant limitations. Hudda et al. (2013) summarizes that tunnel measurements cannot provide variability showing only a central tendency. In contrast, remote sensing only allows for determining an individual vehicle's EF unless large numbers of locations are sampled in a representative manner. Therefore, in this research, we assumed the emission factors suggested by Cancelli and Dias (2014) based

180 on data from the Environmental Agency of São Paulo (CETESB) and the first National Atmospheric Emissions from Road Vehicles Inventory developed by Brazilian Ministry of the Environment (MMA, 2011), which were determined for Brazilian vehicles (Table 1).

\subsection{Spatial Evaluation}

To spatial distribution was been compared with values of Emission Database for Global Atmospheric Research harmonized (EDGAR-HTAP, http://edgar.jrc.ec.europa.eu/htap, Janssens-Maenhout et al., 2012); REanalysis of the TROpospheric chemical composition over the past 40 years (RETRO, http://retro.enes.org) and the urban emissions inventory for South America (Alonso et al, 2010). Thus, version 1.5 of the PREP-CHEM-SRC system (ftp://ftp.cptec.inpe.br/brams/PREP-CHEM/PREP-CHEM-SRC1.5.tar.gz) was utilized to standardize the emission inventories in $1 \mathrm{~km}$ horizontal resolution. PREP-CHEM-SRC is a 
Geosci. Model Dev. Discuss., https://doi.org/10.5194/gmd-2018-81

Manuscript under review for journal Geosci. Model Dev.

Discussion started: 6 June 2018

(c) Author(s) 2018. CC BY 4.0 License.

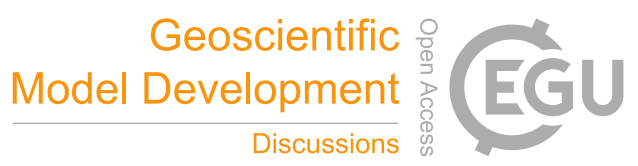

(c) (i)

comprehensive tool that aims to prepare emission fields of trace gases and aerosols for use in atmospheric-chemistry transport

190 models (Freitas et al., 2011).

\section{Resul ts and discussion}

This section introduces our bottom-up vehicle emission inventory for the Manaus urban area, as resulted from applying the methodology described above and data and information locally collected. Traffic density has been intensively monitored for a

195 number of years in the Manaus urban area; however, we only considered the data information for years 2014 and 2015 . Figure 2 introduces the traffic density for the 258 roads for light vehicle, motorcycles, bus and truck, respectively. The thickness of the line on the map relates to the amount of traffic. It can be seen, direction preferential for light vehicles, bus and trucks, while motorcycles show a more homogenous distribution.

Table 2 shows a statistical summary of vehicle emissions from different categories over the study area. The totals of emissions are 4.1, 1.0, 0.37, 0.072, 63.5 and 2.56 ton/h for $\mathrm{CO}, \mathrm{NO}_{\mathrm{x}}, \mathrm{CH}_{4}, \mathrm{PM}, \mathrm{CO}_{2}$ and $\mathrm{NMHC}$, respectively. From these totals the light vehicles are responsible for a large fraction of the pollutants, contributing 2.6, 0.87, 0.32, 0.03, 456 and 0.8 tons/h.

We noted that light vehicles represent about $\sim 62.8 \%, 84.7 \%, 87.9 \%, 45.1 \%, 71.8 \%$, and $33.9 \%$ and motorcycles in the order of $32.28 \%, 6.54 \%, 12.06 \%, 6.19 \%, 14.77 \%$, and $8.71 \%$. Nevertheless, we can highlight the bus emissions which are around $\mathbf{3 5 . 7 4 \%}$ and $45.27 \%$ for NMHC and PM, respectively (Table 3). Réquia Junior et al (2015) found for light vehicles

205 emissions values at Federal District - Brazil equal $68.9 \%$ of CO, $93.6 \%$ of CH4 and $57.9 \%$ of CO2, and for heavy vehicles (bus and trucks) observed values were in the order of $92.9 \%$ and $97.4 \%$ for NHMC and PM, respectively. In a recent study that Silva et al. (2016) conducted from Pelotas, Brazil, results suggested that light vehicles and motorcycles contribute $\sim 63 \%$ and $28 \%$ of $\mathrm{CO}$, respectively, while light vehicles, heavy vehicles (bus and trucks) and motorcycles contribute some $72 \%$ of NMHC, $76 \%$ of $\mathrm{NO}_{\mathrm{x}}$ and $18 \%$ of NMHC. Duarte et al. (2013) suggested that light vehicles in Rio de Janeiro, Brazil, contribute some $60 \%$ of

$210 \mathrm{CO}, 17$ of $\mathrm{NO}_{\mathrm{x}}$ and 2.9 of PM while motorcycles and heavy vehicles emit $90 \%$ and $5.9 \%$, respectively. In addition, Ueda and Tomaz (2011), using information from Campinas, Brazil, showed that light vehicles are responsible for $74 \%$ of CO, while $61 \%$ of $\mathrm{NO}_{\mathrm{x}}$ and $99.9 \%$ of PM are associated with heavy vehicles.

Figure 3 and 4 show the spatial distributions from emission inventories of $\mathrm{CO}$ and $\mathrm{NO}_{\mathrm{x}}$ for four vehicle categories. Although the spatial distribution trends of the pollutants' emissions are similar, there are some differences between categories of vehicles.

215 Analyses of the distribution of emissions show that they are mostly higher in central zones due to the high traffic rate of passenger cars, motorcycles, buses and trucks. This pattern was observed in the results showed in Figure 2. Of note: trucks are not allowed to enter residential areas, which leads to a considerable level of truck-related emissions on suburban roads around Manaus and industrial areas.

To evaluate uncertainty in the spatial distribution and total emission in the urban area of Manaus, we compared the inventory 220 proposed here (Local inventory - LI) with values of EDGAR-HTAP, RETRO and Alonso et al (2010). Despite the efforts to improve the level of detail, significant uncertainties still remain because are adopted different approaches as different spatial disaggregation methods, different resolutions, different criteria and others. For the Manaus urban area Alonso et al (2010) suggested $\mathrm{CO}$ and $\mathrm{NO}_{\mathrm{x}}$ values of 23.93 and $10.16 \mathrm{Gg} \mathrm{year}^{-1}$, respectively. In contrast, the present results show values of CO and $\mathrm{NO}_{\mathrm{x}}$ around 67.34 and $32.86 \mathrm{Gg}$ year $^{-1}$. In general, for the study area, all databases utilized underestimated the total emissions of

$225 \mathrm{CO}$ and $\mathrm{NO}_{\mathrm{x}}$ emissions presented in LI by a factor of $\sim 3$. Similar results were found by Abdallah et al. (2016) for LebanonMiddle East. The comparison of EDGAR-HTAP, RETRO and Alonso et al. (2010) over Manaus highlights the discrepancies between the inventories both in terms of total mass as in spatial distribution. In LI emissions we show a better distribution over 
Geosci. Model Dev. Discuss., https://doi.org/10.5194/gmd-2018-81

Manuscript under review for journal Geosci. Model Dev.

Discussion started: 6 June 2018

(c) Author(s) 2018. CC BY 4.0 License.

(c) (1)

the domain, highlighting major urban roads (Figure 5). The differences between the totals and the spatial distribution may be related with the methods applied but also have a direct relationship with the size of the urban area and number of vehicles

230 considered in the studies. For example, for Manaus Alonso et al. (2010) utilized an area of $\sim 265.32 \mathrm{~km}^{2}$ and a total of $\sim 581,000$ vehicles; in contrast, for the inventory proposed here, we used an area of $\sim 447 \mathrm{~km}^{2}$ and a total of $\sim 622,000$ vehicles.

\section{Conclusion}

This paper introduces a detailed bottom-up vehicular emission inventory developed for Manaus, the capital of Amazonas (Brazil), based on local information and on the city scale. The estimated mobile emissions of $\mathrm{CO}, \mathrm{NO}_{\mathrm{x}}, \mathrm{CH}_{4}, \mathrm{PM} \mathrm{CO}_{2}$ and

$235 \mathrm{NMHC}$ are approximately 4.1, 1.0, 0.37, 0.072, 63.5 and $2.56 \mathrm{ton} / \mathrm{h}$, respectively. In agreement with previous studies over different regions, light vehicles are mainly responsible for the total emissions, accounting for approximately $62.8 \%, 84.7 \%$, $87.9 \%, 45.1 \%, 71.8 \%$, and $33.9 \%$ of the respective total mass of the above pollutants. Motorcycles come in second place participating with $32.3 \%, 6.5 \%, 12.1 \%, 6.2 \%, 14.8 \%$, and $8.7 \%$ of the total mass. However, we can highlight the bus emissions which are $\sim 35.74 \%$ and $45.27 \%$ for NMHC and PM, respectively. Our results indicate that the developed inventory reflects the

240 influences of standard behavior of traffic distribution per vehicle category and better distribution over the domain. Furthermore, this inventory provides more accurate information to improve the current understanding how vehicle emissions contribute to the ambient pollutant concentrations, the direct and indirect impacts on regional climate changes and more detailed scenarios for policymakers and regulatory agencies to develop strategies for controlling the vehicular emissions and, consequently, mitigate associated impacts on local and regional scales of the Amazon ecosystems.

\section{Code and data availability}

Most of the parts that comprise this methodology are publically available. The source code of PREP-CHEM-SRC is maintained and de veloped National Institute of Space Research, Center for Weather Forecasting and Climate Research by the GMAI group (Group Modeling of the Atmosphere and its Interfaces). The code and most of the global and South American emission database are available upon request to the 2nd author or can be downloaded from the ftp://ftp.cptec.inpe.br/brams/PREP-CHEM/PREP-

250 CHEM-SRC-1.5.tar.gz. The new inventory and source code are currently being implemented within the PREP-CHEM-SRC, researchers will be able to access its code and database used in this study, as well as more recent versions, available upon request at no cost, via repository in https://doi.org/10.5281/zenodo.1245811. In addition, researcher interested in the new motor vehicle emission inventory for Manaus urban area and source code is encouraged to contact the corresponding author.

\section{Acknowledgments}

255 This work is part of the $\mathrm{PhD}$ thesis of the first author that is under de velopment at the Post-Graduate Program in Climate and Environment (PPG-CLIAMB) of the National Research Institute of the Amazon (INPA) and the Amazonas State University (UEA) with financial support from Coordination for the Improvement of Higher Education Personnel (CAPES). We acknowledge the support of the Central Office of the Large-Scale Biosphere Atmosphere Experiment in Amazonia (LBA), the National Institute of Research of Amazônia (INPA), National Institute of Space Research (INPE), Center for Weather

260 Forecasting and Climate Research (CPTEC) and the Amazonas State University. We also thank Group Modeling of the Atmosphere and its Interfaces (GMAI) - CPTEC. The first author thanks the CAPES for the grant scholarship, linked to PPGCLIAMB. Thanks also go to Amy Houghton for their very valuable comments to improve this work. 
Geosci. Model Dev. Discuss., https://doi.org/10.5194/gmd-2018-81

Manuscript under review for journal Geosci. Model Dev.

Discussion started: 6 June 2018

(c) Author(s) 2018. CC BY 4.0 License.

\section{References}

Abe, K. and Miraglia, S.: Health Impact Assessment of Air Pollution in São Paulo, Brazil. Int. J. Environ. Res. Public Health, 13, 265 694, doi: 10.3390/ijerph13070694, 2016.

Abdallah, C., Sartelet, K. and Afif, C.: Influence of boundary conditions and anthropogenic emission inventories on simulated O3 and PM2.5 concentrations over Lebanon, Atmospheric Pollution Research, Vol. 7, Issue 6, 971-979, 2016.

Afroz R., Hassan, M. N. and Ibrahim, N. A.: Review of air pollution and health impacts in Malaysia. Environ Res, 92, 71-77. doi: 10.1016/S0013-9351(02)00059-2, 2003.

270 Alonso, M. F., Longo, K. M., Freitas, S. R., Fonseca, R. M., Marçal, V., Pirre, M. and Klenner, L. G.: An urban emissions inventory for south america and its application in numerical modeling of atmospheric chemical composition at local and regional scales. Atmos. Environ., 44, 5072-5083, doi: 10.1016/j.atmosenv.2010.09.013, 2010.

Alves, E. M. P., Costa, R. R., Braga, A. A., Miranda, M., Nascimento, N. C. and Saldiva, P. H. N.: Monitoramento da qualidade do ar no Brasil. São Paulo: Instituto Saúde e Sustentabilidade, 2014.

275 Andrade, M., Ynoue, R., Harley, R. and Miguel, A.: Air Quality Model Simulating Photochemical Formation of Pollutants: The São Paulo Metropolitan Area Brazil Int. J. Environ. Pollut., 22 (4), 460-475, 2004.

Andrade, M. F., Miranda, R. M., Fornaro, A., Kerr, A., Oyama, B., Andre, P.A. and Saldiva, P.: Vehicle emissions and PM2.5 mass concentrations in six Brazilian cities. Air Quality Atmosphere \& Health, doi: 10.1007/s11869-010-0104-5, 2010.

280 cloud over the Amazon, Science, 303, 1337-1342, 2004.

Andreae, M. O.: Aerosols before pollution. Science, 315, 50-51, 2007.

Andreae, M. O., Acevedo, O. C., Araújo, A., Artaxo, P., Barbosa, C. G. G., Barbosa, H. M. J., Brito, J., Carbone, S., Chi, X., Cintra, B. B. L., da Silva, N. F., Dias, N. L., Dias-Júnior, C. Q., Ditas, F., Ditz, R., Godoi, A. F. L., Godoi, R. H. M., Heimann, M., Hoffmann, T., Kesselmeier, J., Könemann, T., Krüger, M. L., Lavric, J. V., Manzi, A. O., Lopes, A. P., Martins, D. L.,

285 Mikhailov, E. F., Moran-Zuloaga, D., Nelson, B. W., Nölscher, A. C., Santos Nogueira, D., Piedade, M. T. F., Pöhlker, C., Pöschl, U., Quesada, C. A., Rizzo, L. V., Ro, C.-U., Ruckteschler, N., Sá, L. D. A., Sá, M. O., Sales, C. B., dos Santos, R. M. N., Saturno, J., Schöngart, J., Sörgel, M., de Souza, C. M., de Souza, R. A. F., Su, H., Targhetta, N., Tota, J., Trebs, I., Trumbore, S., van Eijck, A., Walter, D., Wang, Z., Weber, B., Williams, J., Winderlich, J., Wittmann, F., Wolff, S., and Yáñez-Serrano, A. M.: The Amazon Tall Tower Observatory (ATTO): overview of pilot measurements on ecosystem ecology, meteorology, trace gases,

290 and aerosols, Atmos. Chem. Phys., 15, 10723-10776, doi:10.5194/acp-15-10723-2015, 2015.

Artaxo, P., Oliveira, P., Lara, L. L., Pauliquevis, T. M., Rizzo, L. V., Pires, C., Paixão, M. A., Longo, K. M., Freitas, S. and Correia, A. L.: Efeitos climáticos de partículas de aerossóis biogênicos e emitidos em queimadas na Amazônia. Revista Brasileira de Meteorologia (Impresso), 21, 1-22, 2006.

Artaxo, P., Martins, J. V., Yamasoe, M. A., Procópio, A. S., Pauliquevis, T. M., Andreae, M. O., Gunyon, P., Gatti, L. V., and 295 Leal, A. M. C.: Physical and chemical properties of aerosols in the wet and dry seasons in Rondônia Amazônia, J. Geophys. Res., 107, 1-14, doi: 10.1029/2001JD000666, 2002.

Artaxo, P., Rizzo, L. V., Brito, J. F., Barbosa, H. M. J., Arana, A., Sena, E. T., Cirino, G. G., Bastos, W., Martin, S. T. and Andreae., M. O.: Atmospheric aerosols in Amazonia and land use change: from natural biogenic to biomass burning conditions. Faraday Discuss., 165, 203, 2013.

300 Ashfold, M. J., Pyle, J. A., Robinson, A. D., Meneguz, E., Nadzir, M. S. M., Phang, S. M., Samah, A. A., Ong, S., Ung, H. E., Peng, L. K., Yong, S. E., and Harris, N. R. P.: Rapid transport of East Asian pollution to the deep tropics, Atmos. Chem. Phys., 15,3565-3573, doi:10.5194/acp-15-3565-2015, 2015.

Ban-Weiss, G. A., Lunden, M. M., Kirchstetter, T. W., and Harley, R. A.: Size-resolved particle number and volume emission factors for on-road gasoline and diesel motor vehicles, J. Aerosol Sci., 41, 5-12, 2010. 
Geosci. Model Dev. Discuss., https://doi.org/10.5194/gmd-2018-81

Manuscript under review for journal Geosci. Model Dev.

Discussion started: 6 June 2018

(c) Author(s) 2018. CC BY 4.0 License.

305 Bateman, A. P., Gong, Z., Harder, T. H., de Sá, S. S., Wang, B., Castillo, P., China, S., Liu, Y., O'Brien, R. E., Palm, B. B., Shiu, H.-W., Cirino, G. G., Thalman, R., Adachi, K., Alexander, M. L., Artaxo, P., Bertram, A. K., Buseck, P. R., Gilles, M. K., Jimenez, J. L., Laskin, A., Manzi, A. O., Sedlacek, A., Souza, R. A. F., Wang, J., Zaveri, R., and Martin, S. T.: Anthropogenic influences on the physical state of submicron particulate matter over a tropical forest, Atmos. Chem. Phys., 17, 1759-1773, doi:10.5194/acp-17-1759-2017,2017.

310 Bellasio, R., Bianconi, R., Corda, G. and Cucca, P.: Emission inventory for the road transport sector in Sardinia (Italy). Atmos. Environ. 41 (4), 677-691. https://doi.org/10.1016/j.atmosenv.2006.09.017, 2007.

Betts, R., Sanderson, M. and Woowdward, S.: Effects of large-scale Amazon forest degradation on climate and air quality through fluxes of carbon dioxide, water, energy, mineral dust and isoprene. Phil. Trans. R. Soc. B, 363, 1873-1880, 2008.

Bishop, G. A., Peddle, A. M., Stedman, D. H., and Zhan, T.: Onroad emission measurements of reactive nitrogen compounds

315 from three California cities, Environ. Sci. Technol., 44, 3616-3620, 2010.

Cancelli, D. M. and Dias, N. L. BRe vê: uma metodologia objetiva de cálculo de emissões para a frota brasileira de veículos. Eng. Sanit. Ambient., Rio de Janeiro, 19, n. spe, 13-20, 2014.

Cecchini, M. A., Machado, L. A. T., Comstock, J. M., Mei, F., Wang, J., Fan, J., Tomlinson, J. M., Schmid, B., Albrecht, R., Martin, S. T., and Artaxo, P.: Impacts of the Manaus pollution plume on the microphysical properties of Amazonian warm-phase 320 clouds in the wet season, Atmos. Chem. Phys., 16, 7029-7041, doi:10.5194/acp-16-7029-2016, 2016.

Chapman, L.: Transport and Climate Change: A Review. Journal of Transport Geography, 15, 354-367, 2007.

Coelho, M. C., Fontes, T., Bandeira, J. M., Pereira, S. R., Tchepel, O., Dias, D., Sá, E., Amorim, J. H. and Borrego, C.: Assessment of potential improvements on regional air quality modelling related with implementation of a detailed methodology for traffic emission estimation. Sci. Total Environ. 470-471, 127-137. doi: 10.1016/j.scitotenv.2013.09.042, 2014.

325 de Sá, S. S., Palm, B. B., Campuzano-Jost, P., Day, D. A., Newburn, M. K., Hu, W., Isaacman-VanWertz, G., Yee, L. D., Thalman, R., Brito, J., Carbone, S., Artaxo, P., Goldstein, A. H., Manzi, A. O., Souza, R. A. F., Mei, F., Shilling, J. E., Springston, S. R., Wang, J., Surratt, J. D., Alexander, M. L., Jimenez, J. L., and Martin, S. T.: Influence of urban pollution on the production of organic particulate matter from isoprene epoxydiols in central Amazonia, Atmos. Chem. Phys., 17, 6611-6629, https://doi.org/10.5194/acp-17-6611-2017, 2017.

330 de Souza, D. O. and Alvalá, R. C. dos S.: Observational evidence of the urban heat island of Manaus City, Brazil. Met. Apps, 21, 186-193. doi: 10.1002/met.1340, 2014.

Dios, M, Souto, J. A., Casares, J. J., Gallego, N., Saez, A., Macho, M. L., Cartelle, D. and Vellon, J. M.: A mixed top-down and bottom-up methodology in spatial segregation of emissions based on GIS tools. Proceedings of the Air Pollution 2012 Conference, A Coruña, Spain, 2012.

335 Duarte, C., Souza, R de, Silva, S. D., Aure, M., Agosto, D. A. D. and Barboza, A. P.: Inventory of conventional air pollutant s emissions from road transportation for the state of Rio de Janeiro. Energy Policy 25 (20), 2013.

Ebinger, J., Peltier, N., Gitay, H., Monsalve, C., Losos, A., Rogers, J. A. and Vandycke, N.: Transport at COP21: Part of the Climate Change Solution. Connections; No. 28.World Bank, Washington, DC. ㅇ World Bank, 2015.

Fearnside, P. M.: Fogo e emissão de gases de efeito estufa dos ecossistemas florestais da Amazônia brasileira. Estud. av., São 340 Paulo, 16 (44), 99-123, 2002.

Fisch, G. F., Marengo, J. A. and Nobre, C. A.: Uma revisão geral sobre o Clima da Amazônia. Acta Amazonica, 28, 101-126, 1998.

Freitas, S. R., Longo, K. M., Alonso, M. F., Pirre, M., Marecal, V., Grell, G., Stockler, R., Mello, R. F., and Sánchez Gácita, M.: PREP-CHEM-SRC - 1.0: a preprocessor of trace gas and aerosol emission fields for regional and global atmospheric chemistry 
Geosci. Model Dev. Discuss., https://doi.org/10.5194/gmd-2018-81

Manuscript under review for journal Geosci. Model Dev.

Discussion started: 6 June 2018

(c) Author(s) 2018. CC BY 4.0 License.

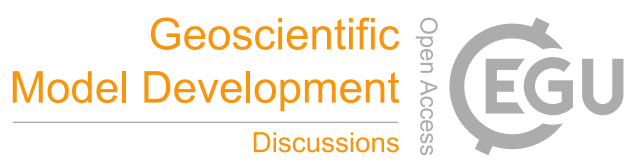

Freud, E., Rosenfeld, D., Andreae, M. O., Costa, A. A., and Artaxo, P.: Robust relations between CCN and the vertical evolution of cloud drop size distribution in deep convective clouds, Atmos. Chem. Phys., 8, 1661-1675, https://doi.org/10.5194/acp-81661-2008, 2008 .

Gallardo, L., Escribano, J., Dawidowski, L., Rojas, N., Andrade, F.M. and Osses, M.: Evaluation of vehicle emission inventor ies 350 for carbon monoxide and nitrogen oxides for Bogota, Buenos Aires, Santiago, and São Paulo. Atmos. Environ. 47, $12-19$. http://dx.doi.org/10.1016/j.atmosenv.2011.11.051,2012.

Hudda, N., Fruin, S., Delfino, R. J., and Sioutas, C.: Efficient determination of vehicle emission factors by fuel use category using on-road measurements: downward trends on Los Angeles freight corridor I-710, Atmos. Chem. Phys., 13, 347-357, https://doi.org/10.5194/acp-13-347-2013, 2013.

355 IBGE: Estimates of the resident population in Brazil and Federative Units from Brazilian Institute of Geography and Statistics., 2015.

IPCC: Climate Change. Synthesis Report. Contribution of Working Groups I, II and III to the Fifth Assessment Report of the Intergovernmental Panel on Climate Change [Core Writing Team, R.K. Pachauri and L.A. Meyer (eds.)]. IPCC, Geneva, Switzerland, 151, 2014.

360 Janssens-Maenhout, G., Dentener, F., van Aardenne, J., Monni, S., Pagliari, V., Orlandini, L., Klimont, Z., Kurokawa, J., Akimoto, H., Ohara, T., Wankmüller, R., Battye, B., Grano, D., Zuber, A., and Keating, T.: EDGAR-HTAP: a harmonized gridded air pollution emission dataset based on national inventories, EUR 25229 EN Report, ISBN 978-92-79-23122-3, ISSN 1018-5593, doi:10.2788/14069, 2012.

Janssens-Maenhout, G., Crippa, M., Guizzardi, D., Dentener, F., Muntean, M., Pouliot, G., Keating, T., Zhang, Q., Kurokawa, J.,

365 Wankmüller, R., Denier van der Gon, H., Kuenen, J. J. P., Klimont, Z., Frost, G., Darras, S., Koffi, B., and Li, M.: HTAP_v2.2: a mosaic of regional and global emission grid maps for 2008 and 2010 to study hemispheric transport of air pollution, Atmos. Chem. Phys., 15, 11411-11432, https://doi.org/10.5194/acp-15-11411-2015, 2015

Jing, B., Wu, L., Mao, H., Gong, S., He, J., Zou, C., Song, G., Li, X., and Wu, Z.: De velopment of a vehicle emission inventory with high temporal-spatial resolution based on NRT traffic data and its impact on air pollution in Beijing - Part 1: Development

370 and e valuation of vehicle emission inventory, Atmos. Chem. Phys., 16, 3161-3170, doi:10.5194/acp-16-3161-2016, 2016.

Kahn Ribeiro, S., S. Kobayashi, M. Beuthe, J. Gasca, D. Greene, D. S. Lee, Y. Muromachi, P. J. Newton, S. Plotkin, D. Sperling, R. Wit, P. J. Zhou. Transport and its infrastructure. In Climate Change: Mitigation. Contribution of Working Group III to the Fourth Assessment Report of the Intergovernmental Panel on Climate Change [B. Metz, O.R. Davidson, P.R. Bosch, R. Dave, L.A. Meyer (eds.)], Cambridge University Press, Cambridge, United Kingdom, 2007.

375 Karagulian, F., C.A. Belis, C. Francisco, C. Dora, A.M. Prüss-Ustün, S. Bonjour, H. Adair-Rohani, and M. Amann. Contributions to cities' ambient particulate matter (PM): A systematic review of local source contributions at global level. Atmos. Environ. 120:475-483. doi: 10.1016/j.atmosenv.2015.08.087, 2015.

Kuenen, J. J. P., Visschedijk, A. J. H., Jozwicka, M., Denier van der Gon H. A. C.: TNO-MACC_II emission inventory; a multiyear (2003-2009) consistent high-resolution European emission inventory for air quality modelling. Atmospheric Chemistry and

380 Physics, 14(20), 10963-10976, 2014.

Kuhn, U., Ganze veld, L., Thielmann, A., Dindorf, T., Schebeske, G., Welling, M., Sciare, J., Roberts, G., Meixner, F. X., Kesselmeier, J., Lelieveld, J., Kolle, O., Ciccioli, P., Lloyd, J., Trentmann, J., Artaxo, P., and Andreae, M. O.: Impact of Manaus City on the Amazon Green Ocean atmosphere: ozone production, precursor sensitivity and aerosol load. Atmospheric Chemistry and Physics, 10, 19, 9251-9282, doi: 10.5194/acp-10-9251-2010, 2010.

385 Lozhkina, O.V., and Lozhkin,V.N.: Estimation of road transport related air pollution in Saint Petersburg using European and Russian calculation models. Transport. Res. Part D Transport Environ. 36: 178-189. doi: 10.1016/j.trd.2015.02.013, 2015.

Marengo, J. A. and Espinoza, J. C.: Extreme seasonal droughts and floods in Amazonia: causes, trends and impacts. Int. J. Climatol..doi: 10.1002/joc.4420, 2015.

Martin, S. T., Andreae, M. O., Artaxo, P., Baumgardner, D., Chen, Q., Goldstein, A. H., Guenther, A., Heald, C. L., 390 MayolBracero, O. L., McMurry, P. H., Pauliquevis, T., P”oschl, U., Prather, K. A., Roberts, G. C., Saleska, S. R., Silva-Dias, M. 
Geosci. Model Dev. Discuss., https://doi.org/10.5194/gmd-2018-81

Manuscript under review for journal Geosci. Model Dev.

Discussion started: 6 June 2018

(c) Author(s) 2018. CC BY 4.0 License.

A., Spracklen, D. V., Swietlicki, E., and Trebs, I.: Sources and properties of Amazonian aerosol particles, Rev. Geophys., 48, RG 2002, doi:10.1029/2008RG000280, 2010.

Martin, S. T., Artaxo, P., Machado, L., Manzi, A. O., Souza, R. A., Schumacher, C., Wang, J., Biscaro, T., Brito, J., Calheiros, A., Jardine, K., Medeiros, A., Portela, B., Sa, S. S. de, Adachi, K., Aiken, A. C., Albrecht, R., Alexander, L., Andreae, M. O.,

395 Barbosa, H. M., Buseck, P., Chand, D., Comstock, J. M., Day, D. A., Dubey, M., Fan, J., Fast, J., Fisch, G., Fortner, E., Giangrande, S., Gilles, M., Goldstein, A. H., Guenther, A., Hubbe, J., Jensen, M., Jimenez, J. L., Keutsch, F. N., Kim, S., Kuang, C., Laskin, A., McKinney, K., Mei, F., Miller, M., Nascimento, R., Pauliquevis, T., Pekour, M., Peres, J., Petaja, T., Pohike r, C., Poschi, U., Rizzo, L., Schmid, B., Shilling, J. E., Silva Dias, M. A., Smith, J. N., Tomlinson, J. M., Tota, J., and Wendisch, M.: The Green Ocean Amazon Experiment (GoAmazon2014/5) Observes Pollution Affecting Gases, Aerosols, Clouds, and Rainfall over the Rain Forest. Bulletin of the American Meteorological Society, 10.1175/bams-d-15-00221.1, 2016.

Martins, J. A. and Silva Dias, M. A. F.: The impact of smoke from forest fires on the spectral dispersion of cloud droplet size distributions in the Amazonian region, Environ. Res. Lett., 4, 015002, doi:10.1088/1748-9326/4/1/015002, 2009.

Martins, L. D., Andrade, M. F., Freitas, E. D., Pretto, A., Gatti, L. V., Albuquerque, E.L., Tomaz, E., Guardani, M. L., Mart ins, M. H. R. B. and Junior, O. M. A.: Emission factors for gás-powered vehicles traveling through Road tunnels in São Paulo City,

405 Brasil. Environmental Science \& Technology, 40, 6722-6729, 2006.

Medeiros, A. S. S., Calderaro, G., Guimarães, P. C., Magalhaes, M. R., Morais, M. V. B., Rafee, S. A. A., Ribeiro, I. O., Andreoli, R. V., Martins, J. A., Martins, L. D., Martin, S. T., and Souza, R. A. F.: Power plant fuel switching and air quality in a tropical, forested environment, Atmos. Chem. Phys., 17, 8987-8998, https://doi.org/10.5194/acp-17-8987-2017, 2017.

MMA.: $1^{\circ}$ Inventario Nacional de Emissões Atmosféricas Por Veículos Automotores Rodoviários, first ed. Ministério do Meio

410 Ambiente, Brasília, Brasil, 2011.

Nagpure, A. S., and Gurjar, B. R.: Development and evaluation of vehicular air pollution inventory model. Atmos. Environ. 59:160-169. doi: 10.1016/j.atmosenv.2012.04.044, 2012.

Nobre, P., Malagutti, M., Urbano, D. F., de Almeida, R. A. F. and Giarolla, E.: Amazon deforestation and climate change in a coupled model simulation, J. Clim., 22, 5686-5697, 2009.

415 Puliafito, S. E., Allende, D. G., Castesana, P. S. and Ruggeri, M. F.: High-resolution atmospheric emission inventory of the argentine energy sector. Comparison with edgar global emission database, Heliyon, 3 (12), Article e00489, ISSN 2405-8440, https://doi.org/10.1016/j.heliyon.2017.e00489, 2017.

Puliafito, S. E., Allende, D. G., Pinto, S. and Castesana, P. S.: High Resolution Inventory of GHG Emissions of the Road Transport Sector in Argentina Atmospheric Environ., 101, 303-311, 2015.

420 Ramanathan, V., Crutzen, P. J., Kiehl, J. T. and Rosenfeld, D.: Atmosphere - Aerosols, Climate, and the Hydrological Cycle. Science 294: 2119-2124, 2001.

Réquia, W. J., Koutrakis, P. and Roig, H. L.: Spatial distribution of vehicle emission inventories in the Federal District, Brazil. Atmos. Environ. 112:32-39. doi:10.1016/j.atmosenv.2015.04.029, 2015.

Rizzo, L. V., Artaxo, P., Müller, T., Wiedensohler, A., Paixão, M., Cirino, G. G., Arana, A., Swietlicki, E., Roldin, P., Fors, E.

425 O., Wiedemann, K. T., Leal, L. S. M., and Kulmala, M.: Long term measurements of aerosol optical properties at a primary forest site in Amazonia, Atmos. Chem. Phys., 13, 2391-2413, doi:10.5194/acp-13-2391-2013, 2013.

Roberts, G. C., Nenes, A., Seinfeld, J. H. and Andreae, M. O.: Impact of biomass burning on cloud properties in the Amazon Basin, J. Geophys. Res., 108, 4062, doi:10.1029/2001JD000985, 2003.

Rogelj, J., den Elzen, M., Höhne, N., Fransen, T., Fekete, H., Winkler, H., Schaeffer, R., Sha, F., Riahi, K. and Meinshausen, M.:

430 Paris Agreement climate proposals need a boost to keep warming well below $2^{\circ} \mathrm{C}$. Nature 534: 631-639. doi:10.1038/nature 18307, 2016.

Santos, M. J., Silva Dias, M. A. and Freitas, E. D.: Influence of local circulations on wind, moisture, and precipitation close to Manaus City, Amazon Region, Brazil. Journal of Geophysical Research, 2014. 
Geosci. Model Dev. Discuss., https://doi.org/10.5194/gmd-2018-81

Manuscript under review for journal Geosci. Model Dev.

Discussion started: 6 June 2018

(c) Author(s) 2018. CC BY 4.0 License.

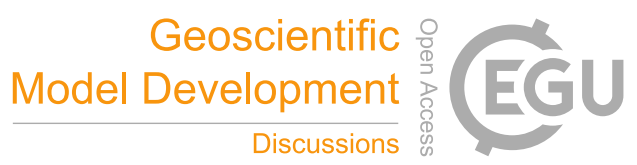

(c) (i)

Scovronick, N., França, D., Alonso, M., Almeida, C., Longo, K., Freitas, S., Rudorff, B. and Wilkinson, P.: Air Quality and 435 Health Impacts of Future Ethanol Production and Use in São Paulo State, Brazil. Int. J. Environ. Res. Public Health. 13:695. doi: 10.3390/ijerph13070695, 2016.

Silva, K. L. A., Alonso, M. F. and Oliveira, L.: Analysis of Mobile Sources Atmospheric Emissions in Pelotas City. Ciência e Natura, 38, 347-353, 2016.

Sims, R., Schaeffer, R., Creutzig, F., Cruz-Núñez, X., D’Agosto, M., Dimitriu, D., Figueroa Meza, M. J., Fulton, L., Kobayashi,

440 S., Lah, O., McKinnon, A., Newman, P., Ouyang, M., Schauer, J. J., Sperling, D. and Tiwari, G..: Transport. In: Climate Change 2014: Mitigation of Climate Change. Contribution of Working Group III to the Fifth Assessment Report of the Intergovernmental Panel on Climate Change [Edenhofer, O., Pichs-Madruga, R., Sokona, Y., Farahani, E., Kadner, S., Seyboth, K., Adler, A., Baum, I., Brunner, S., Eickemeier, P., Kriemann, B., Savolainen, J., Schlömer, S., von Stechow, C., Zwickel, T. and Minx, J. C. (eds.)]. Cambridge University Press, Cambridge, United Kingdom and New York, NY, USA, 2014.

445 Sokhi, R. S.: World Atlas of Atmospheric Pollution. Edited by Ranjeet S. Sokhi. 1st ed. Nova York: Anthen press, 2011.

Song, X. Y. and Xie, S. D.: Development of vehicle emission inventory in China, Environb. Sci., 27, 1041-1045, 2006.

Soylu, S.: Estimation of Turkish road transport emissions, Energy Policy, 35 (8), 4088-4094, ISSN 0301-4215, http://dx.doi.org/10.1016/j.enpol.2007.02.015, 2007.

Stanley, J. K., Hensher, D. A. and Loader, C.: Road transport and climate change: Stepping off the greenhouse

450 gas. Transportation Research Part A: Policy and Practice 45.10, 1020-1030, 2011.

Trebs, I., Mayol-Bracero, O. L., Pauliquevis, T., Kuhn, U., Sander, R. and Ganze veld, L: Impact of the Manaus urban plume on trace gas mixing ratios near the surface in the Amazon Basin: Implications for the NO-NO2-O3 photostationary state and peroxy radical levels, J. Geophys. Res., 117, D05307, 2012.

Trombetti, M., Pisoni, E., Lavalle, C.: Downscaling methodology to produce a high resolution gridded emission inventory to support local/city level air quality policies, EUR $28428 \mathrm{EN}$, doi:10.2760/51058, 2017.

Ueda, A.C. and Tomaz, E.: Inventario de emissão de fontes veiculares da região metropolinata de Campinas, Sao Paulo. Quim. Nova 34 (9), 1496-1500, 2011.

UNEP. The Emissions Gap Report 2017. United Nations Environment Programme (UNEP), Nairobi, 2017.

Vara-Vela, A., Andrade, M. F., Kumar, P., Ynoue, R. Y., and Muñoz, A. G.: Impact of vehicular emissions on the formation of 460 fine particles in the Sao Paulo Metropolitan Area: a numerical study with the WRF-Chem model, Atmos. Chem. Phys., 16, 777797, doi:10.5194/acp-16-777-2016, 2016.

Vasconcellos, E.A.: Transporte e Meio Ambiente, first ed. Annablume, São Paulo, p. 200, 2006.

Venegas, L. E., Mazzeo, N. A. and Rojas, A. L. P.: Evaluation of an Emission Inventory and Air Pollution in the Metropolitan Area of Buenos Aires, Air Quality-Models and Applications, Prof. Dragana Popovic (Ed.), InTech, doi: 10.5772/18767, 2011.

465 Vivanco, M. G. and Andrade, M. F.: Validation of the emission inventory in the Sao Paulo Metropolitan Area of Brazil, based on ambient concentrations ratios of $\mathrm{CO}, \mathrm{NMOG}$ and $\mathrm{NO}_{\mathrm{x}}$ and on a photochemical model. Atmospheric Environ., 40 (7), 1189-1198, 2006.

Wang, H., and Fu, R.: The influence of Amazon rainfall on the Atlantic ITCZ through convectively coupled Kelvin waves. J. Climate, 20, 1188-1201, 2007.

470 Yoshizaki, K., Brito, J. M., Silva, L. F., Franco, A. L. dos S., Frias, D. P., e Silva, R. C. R., Lourenço, L. F. A., Saldiva, P. H. N., Tibério, I. de F. L. C., Mauad, T. and Macchione, M.: The effects of particulate matter on inflammation of respiratory system: Differences between male and female. Science of the Total Environment, 586, 15, 2017.

Zhou, Y., Cheng, S., Chen, D., Lang, J., Zhao, B. and Wei, W.: A new statistical approach for establishing high-resolution emission inventory of primary gaseous air pollutants. Atmos. Environ. 94, 392-401. http://dx.doi.org/10.1016/ j.atmosenv.2014.05.047, 2014. 
Geosci. Model Dev. Discuss., https://doi.org/10.5194/gmd-2018-81

Manuscript under review for journal Geosci. Model Dev.

Discussion started: 6 June 2018

(c) Author(s) 2018. CC BY 4.0 License.

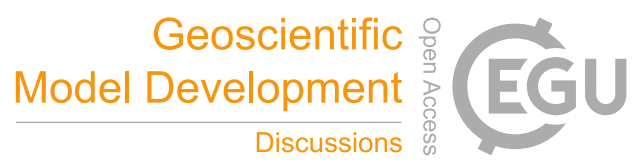

(c) (1)

Zhou, Y., Zhao, Y., Mao, P., Zhang, Q., Zhang, J., Qiu, L. and Yang, Y.: De velopment of a high-resolution emission inventory and its evaluation and application through air quality modeling for Jiangsu Province, China, Atmos. Chem. Phys., 17, 211-233, doi:10.5194/acp-17-211-2017, 2017. 
Geosci. Model Dev. Discuss., https://doi.org/10.5194/gmd-2018-81 Manuscript under review for journal Geosci. Model Dev.

Discussion started: 6 June 2018

(c) Author(s) 2018. CC BY 4.0 License.

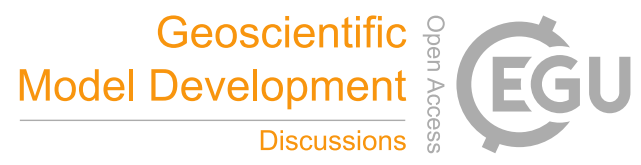

(c) (1)

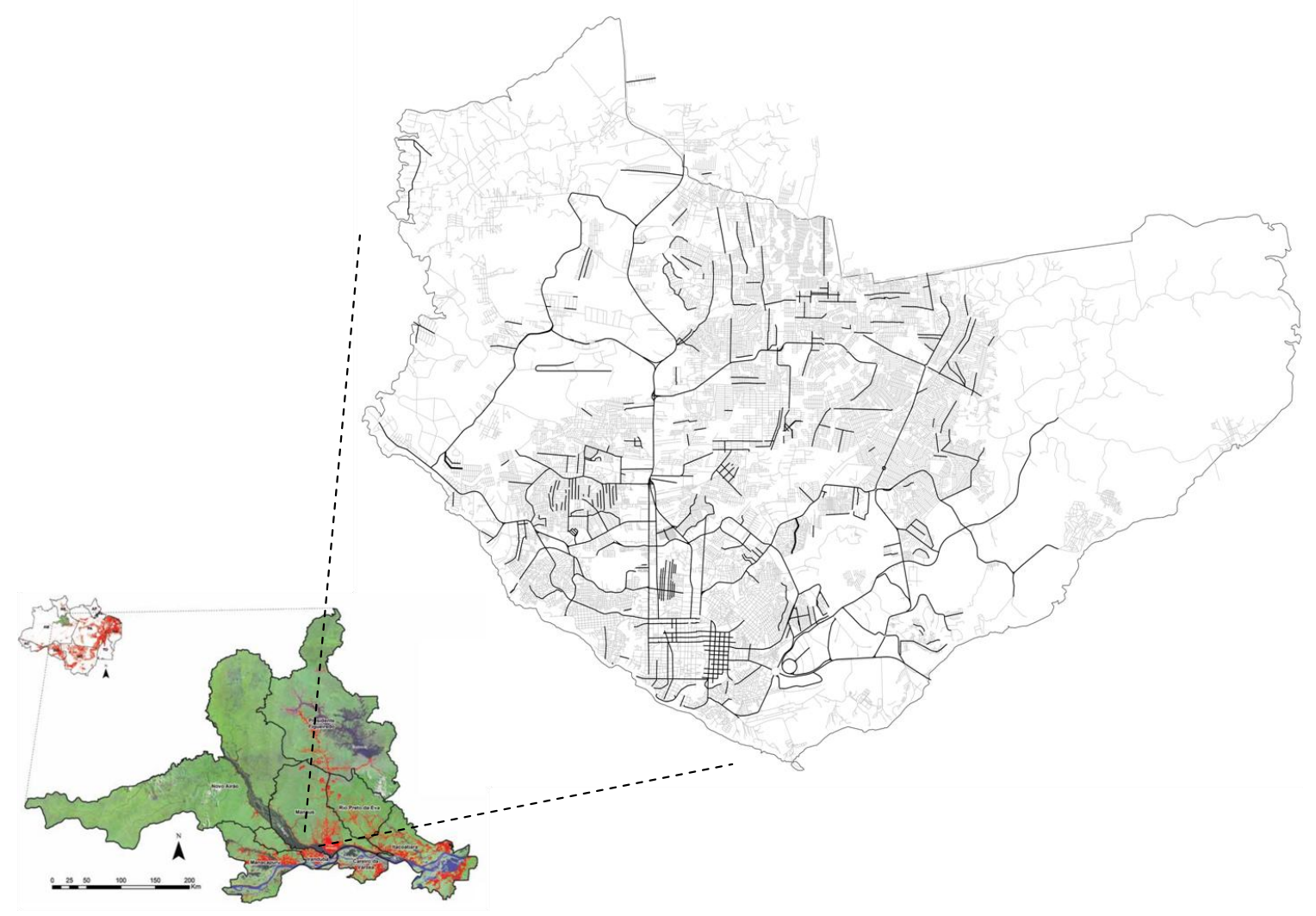

Figure 1. Area of study. Left map represents the metropolitan region of Manaus (areas in green represent forest cover and dark lines are the municipal boundaries; area in red represents deforestation accumulated until March 2014). The map in the upper-right corner shows Manaus' urban area. The black lines represent the main roads, and grey lines are small roads. 
Geosci. Model Dev. Discuss., https://doi.org/10.5194/gmd-2018-81

Manuscript under review for journal Geosci. Model Dev.

Discussion started: 6 June 2018

(c) Author(s) 2018. CC BY 4.0 License.

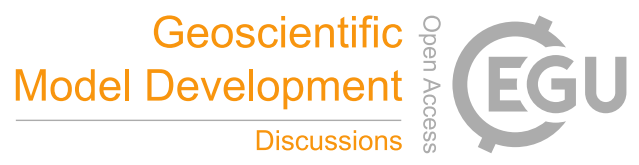

495

500 Table 1. Emission factors ( $\mathrm{g} \mathrm{km}^{-1}$ ) for the total number of vehicles per category (Cancelli and Dias, 2014).

\begin{tabular}{lrrrr}
\hline \hline & light vehicles & motorcycles & bus & trucks \\
\hline $\mathrm{CO}$ & 1.2 & 3 & 1.1 & 1 \\
$\mathrm{NO}_{\mathrm{x}}$ & 0.4 & 0.15 & 0.5 & 0.4 \\
$\mathrm{CH}_{4}$ & 0.15 & 0.1 & 0 & 0 \\
$\mathrm{MP}$ & 0.015 & 0.01 & 0.2 & 0.15 \\
$\mathrm{CO}_{2}$ & 210 & 210 & 445 & 445 \\
$\mathrm{NMHC}$ & 0.4 & 0.5 & 9 & 5 \\
\hline \hline
\end{tabular}

505 
Geosci. Model Dev. Discuss., https://doi.org/10.5194/gmd-2018-81

Manuscript under review for journal Geosci. Model Dev.

Discussion started: 6 June 2018

(c) Author(s) 2018. CC BY 4.0 License.

Table 2. Descriptive statistics for pollutant vehicle emission $(\mathrm{kg} / \mathrm{h})$ of total number of vehicles per category for Manaus urban area using 258 roads.

\begin{tabular}{|c|c|c|c|c|c|c|c|}
\hline \multirow{7}{*}{$\begin{array}{l}\frac{0}{0} \\
: 0 \\
0 \\
0 \\
0 \\
0.00 \\
=0\end{array}$} & & $\mathrm{CO}$ & $\mathrm{NO}_{\mathrm{x}}$ & $\mathrm{CH}_{4}$ & $\mathrm{PM}$ & $\mathrm{CO}_{2}$ & NMHC \\
\hline & Average & 10.108 & 3.369 & 1.263 & 0.126 & 1768.815 & 3.369 \\
\hline & standard de viation & 16.006 & 5.335 & 2.001 & 0.200 & 2801.024 & 5.335 \\
\hline & variation coefficient & 1.584 & 1.584 & 1.584 & 1.584 & 1.584 & 1.584 \\
\hline & Minimum & 0.138 & 0.046 & 0.017 & 0.002 & 24.234 & 0.046 \\
\hline & Maximum & 151.006 & 50.335 & 18.876 & 1.888 & 26426.006 & 50.335 \\
\hline & Total & 2607.739 & 869.246 & 325.967 & 32.597 & 456354.276 & 869.246 \\
\hline \multirow{7}{*}{ 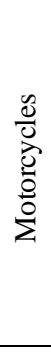 } & & $\mathrm{CO}$ & $\mathrm{NO}_{\mathrm{x}}$ & $\mathrm{CH}_{4}$ & PM & $\mathrm{CO}_{2}$ & NMHC \\
\hline & Average & 5.196 & 0.260 & 0.173 & 0.017 & 363.714 & 0.866 \\
\hline & standard de viation & 7.554 & 0.378 & 0.252 & 0.025 & 528.754 & 1.259 \\
\hline & variation coefficient & 1.454 & 1.454 & 1.454 & 1.454 & 1.454 & 1.454 \\
\hline & Minimum & 0.063 & 0.003 & 0.002 & 0.000 & 4.406 & 0.010 \\
\hline & Maximum & 55.247 & 2.762 & 1.842 & 0.184 & 3867.309 & 9.208 \\
\hline & Total & 1340.545 & 67.027 & 44.685 & 4.468 & 93838.161 & 223.424 \\
\hline \multirow{7}{*}{ 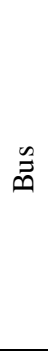 } & & $\mathrm{CO}$ & $\mathrm{NO}_{\mathrm{x}}$ & $\mathrm{CH}_{4}$ & $\mathrm{PM}$ & $\mathrm{CO}_{2}$ & NMHC \\
\hline & Average & 0.550 & 0.250 & $*$ & 0.100 & 222.525 & 4.501 \\
\hline & standard de viation & 0.917 & 0.417 & $*$ & 0.167 & 371.092 & 7.505 \\
\hline & variation coefficient & 1.668 & 1.668 & $*$ & 1.668 & 1.668 & 1.668 \\
\hline & Minimum & 0.008 & 0.004 & $*$ & 0.001 & 3.175 & 0.064 \\
\hline & Maximum & 8.359 & 3.800 & $*$ & 1.520 & 3381.649 & 68.393 \\
\hline & Total & 141.916 & 64.507 & $*$ & 25.803 & 57411.443 & 1161.130 \\
\hline \multirow{7}{*}{$\frac{\vartheta}{\underline{E}}$} & & $\mathrm{CO}$ & $\mathrm{NO}_{\mathrm{x}}$ & $\mathrm{CH}_{4}$ & PM & $\mathrm{CO}_{2}$ & NMHC \\
\hline & Average & 0.241 & 0.096 & $*$ & 0.036 & 107.284 & 1.205 \\
\hline & standard de viation & 0.484 & 0.194 & $*$ & 0.073 & 215.360 & 2.420 \\
\hline & variation coefficient & 2.007 & 2.007 & $*$ & 2.016 & 2.007 & 2.007 \\
\hline & Minimum & 0.002 & 0.001 & $*$ & 0.000 & 0.809 & 0.009 \\
\hline & Maximum & 5.616 & 2.246 & $*$ & 0.842 & 2498.939 & 28.078 \\
\hline & Total & 62.201 & 24.880 & $*$ & 9.330 & 27679.313 & 311.004 \\
\hline
\end{tabular}


Geosci. Model Dev. Discuss., https://doi.org/10.5194/gmd-2018-81

Manuscript under review for journal Geosci. Model Dev.

Discussion started: 6 June 2018

(c) Author(s) 2018. CC BY 4.0 License.

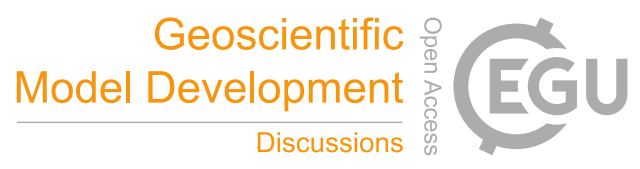

515

Table 3. Summary of the contributions, in percentages, from air pollutant emission for each vehi cle type, for Manaus urban area using 258 roads.

520

\begin{tabular}{lrrrrrr}
\hline Vehicle category & $\mathrm{CO}(\%)$ & $\mathrm{NO}_{x}(\%)$ & $\mathrm{CH}_{4}(\%)$ & $\mathrm{PM}(\%)$ & $\mathrm{CO}_{2}(\%)$ & $\mathrm{NMHC}(\%)$ \\
\hline light vehices & 62.80 & 84.75 & 87.94 & 45.15 & 71.83 & 33.89 \\
Motorcycles & 32.28 & 6.54 & 12.06 & 6.19 & 14.77 & 8.71 \\
Bus & 3.42 & 6.29 & $*$ & 35.74 & 9.04 & 45.27 \\
Trucks & 1.50 & 2.43 & $*$ & 12.92 & 4.36 & 12.13 \\
Total & 100 & 100 & 100 & 100 & 100 & 100 \\
\hline
\end{tabular}

Note: * no calculated

525

530 
Geosci. Model Dev. Discuss., https://doi.org/10.5194/gmd-2018-81

Manuscript under review for journal Geosci. Model Dev.

Discussion started: 6 June 2018

(c) Author(s) 2018. CC BY 4.0 License.

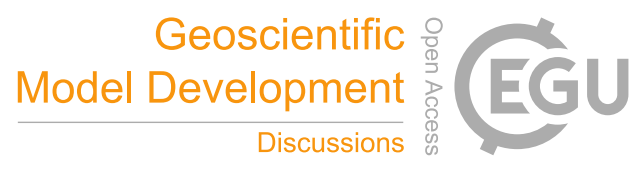

(c) (i)
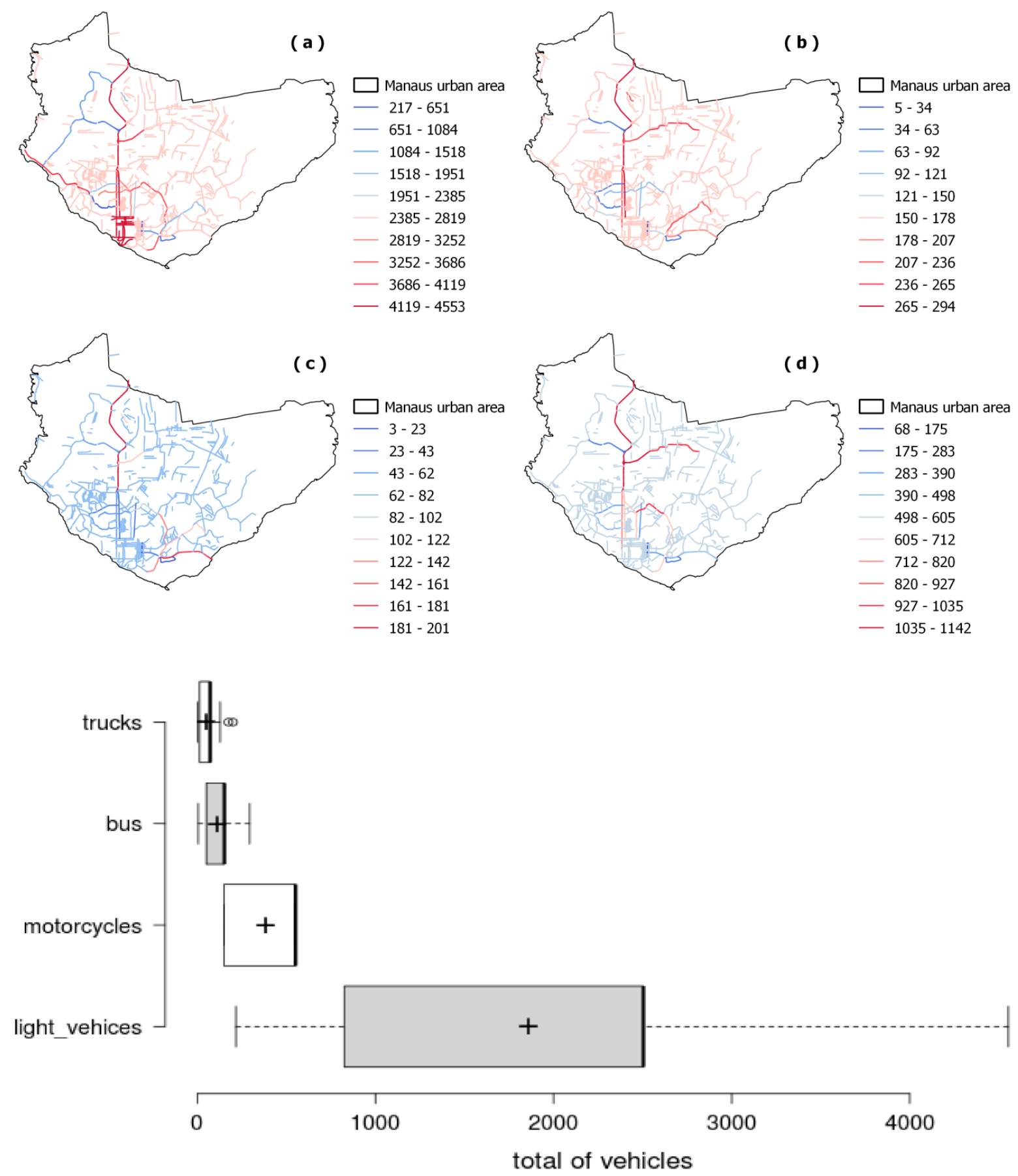

535 Figure 2. The top panel shows the spatial distribution of traffic density in main roads for each vehicle category, respectively: light vehicles (a); bus (b); trucks (c); motorcycles (d). The bottom panel shows the boxplot for each vehicle category. Upper and lower whiskers represent 1.5 interquartile ranges for the period, from the $25^{\text {th }}$ and $75^{\text {th }}$ percentiles; outliers are represented by dots. The crosses represent sample median value and the black square is the average value. 
Geosci. Model Dev. Discuss., https://doi.org/10.5194/gmd-2018-81

Manuscript under review for journal Geosci. Model Dev.

Discussion started: 6 June 2018

(c) Author(s) 2018. CC BY 4.0 License.

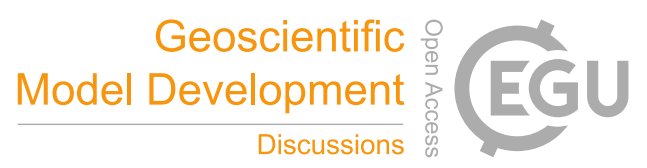

(c) (i)

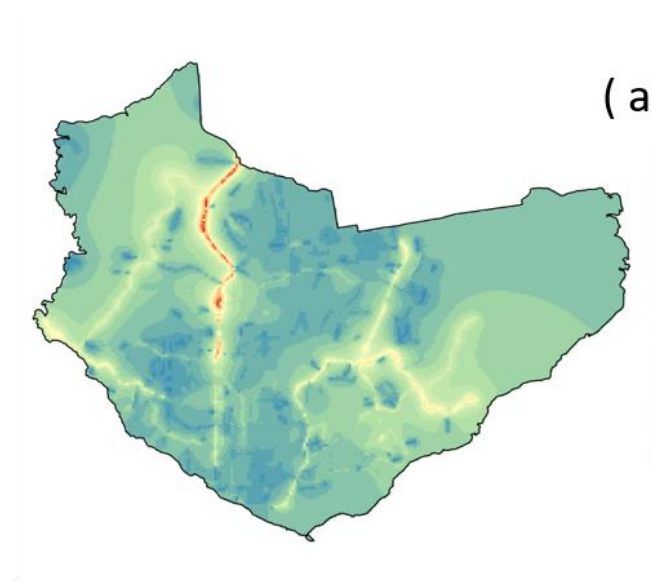

(a)

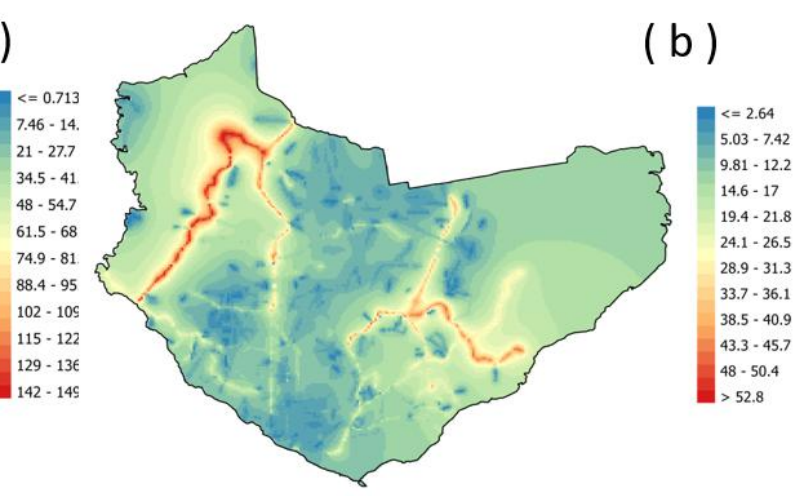

540
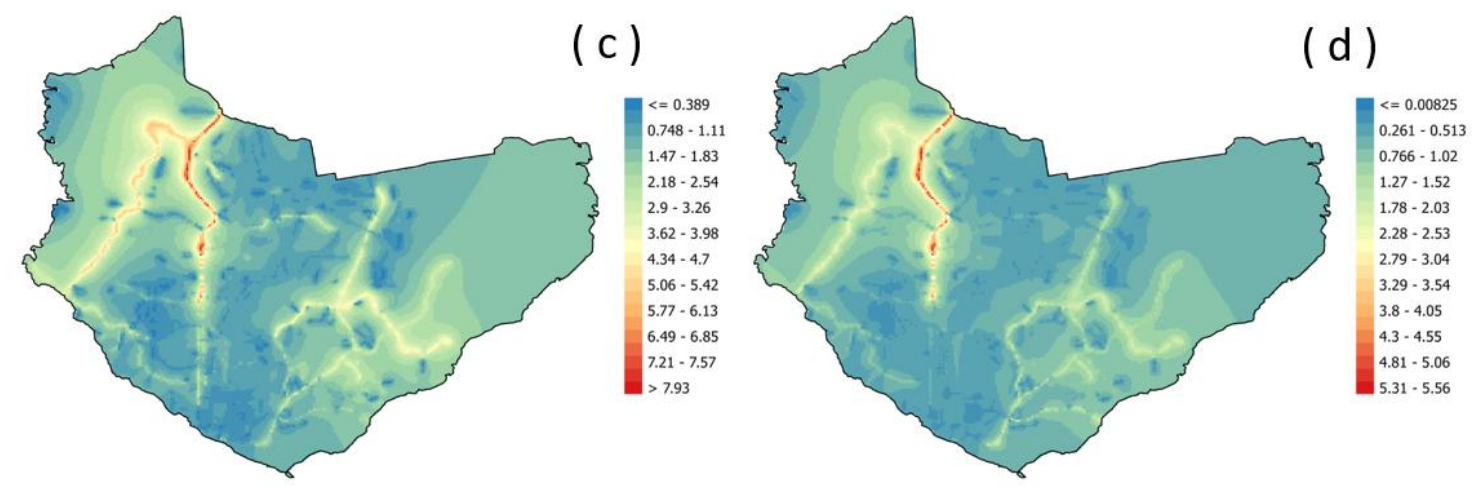

Figure 3. Spatial distribution of $\mathrm{CO}$ at Manaus urban area for each vehicle category in $\mathrm{kg} \mathrm{h}^{-1}$, respectively: light vehicles (a); motorcycles (b); bus (c); trucks (d). 
Geosci. Model Dev. Discuss., https://doi.org/10.5194/gmd-2018-81

Manuscript under review for journal Geosci. Model Dev.

Discussion started: 6 June 2018

(c) Author(s) 2018. CC BY 4.0 License.

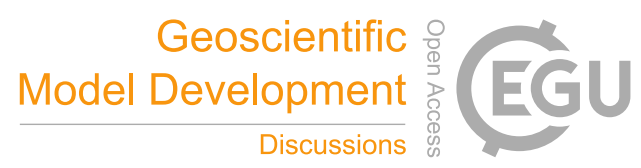

(c) (i)

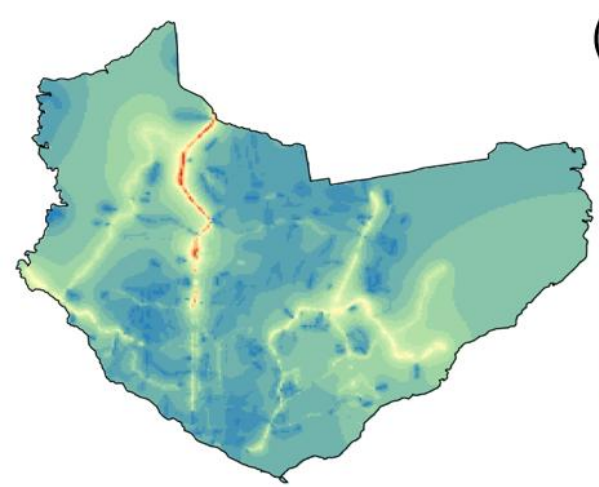

( a )
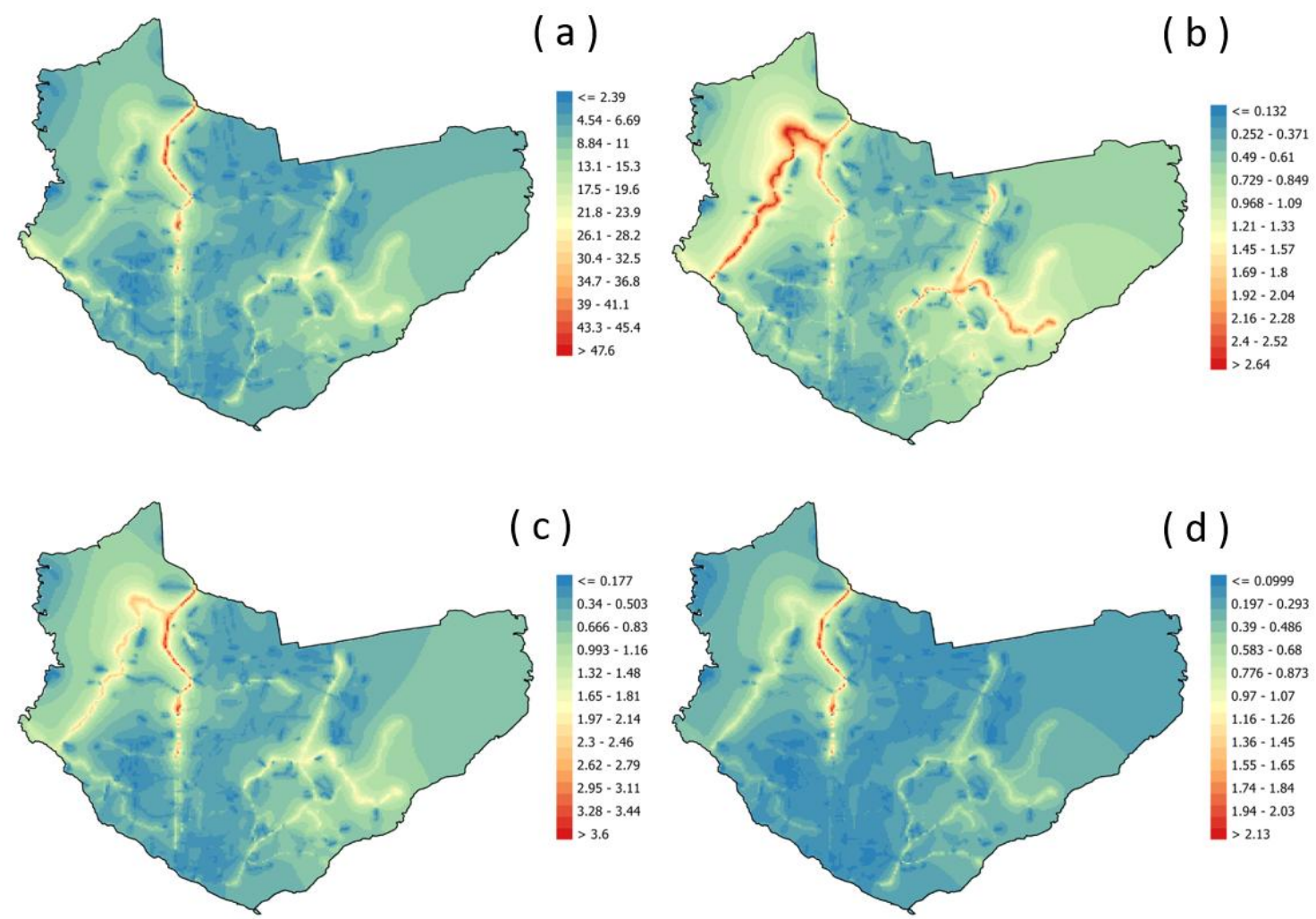

(c)
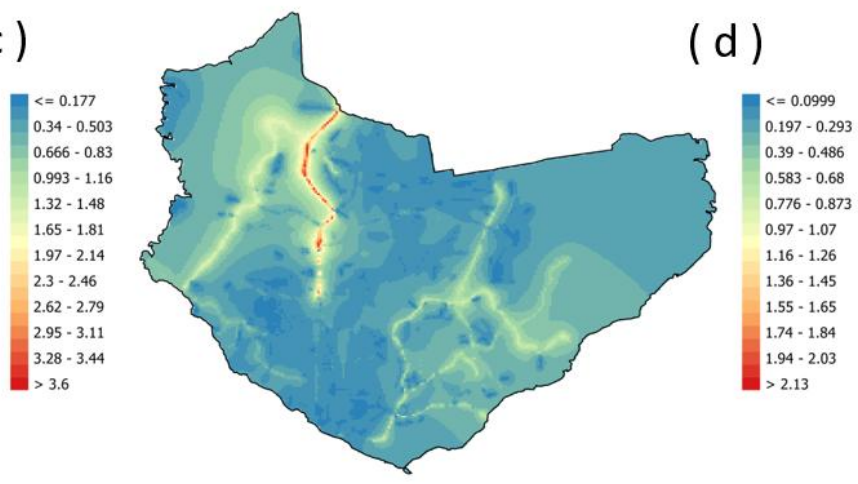

Figure 4. Spatial distribution of $\mathrm{NO}_{\mathrm{x}}$ at Manaus urban area for each vehicle category in $\mathrm{kg} \mathrm{h}^{-1}$, respectively: light vehicles (a); motorcycles (b); bus (c); trucks (d). 
Geosci. Model Dev. Discuss., https://doi.org/10.5194/gmd-2018-81 Manuscript under review for journal Geosci. Model Dev.

Discussion started: 6 June 2018

(c) Author(s) 2018. CC BY 4.0 License.

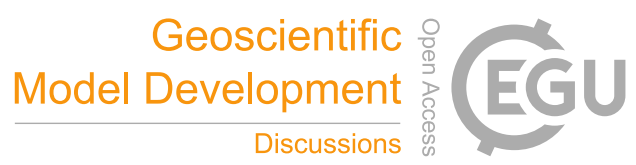

(c) $\underset{\mathrm{BY}}{(\mathrm{P}}$

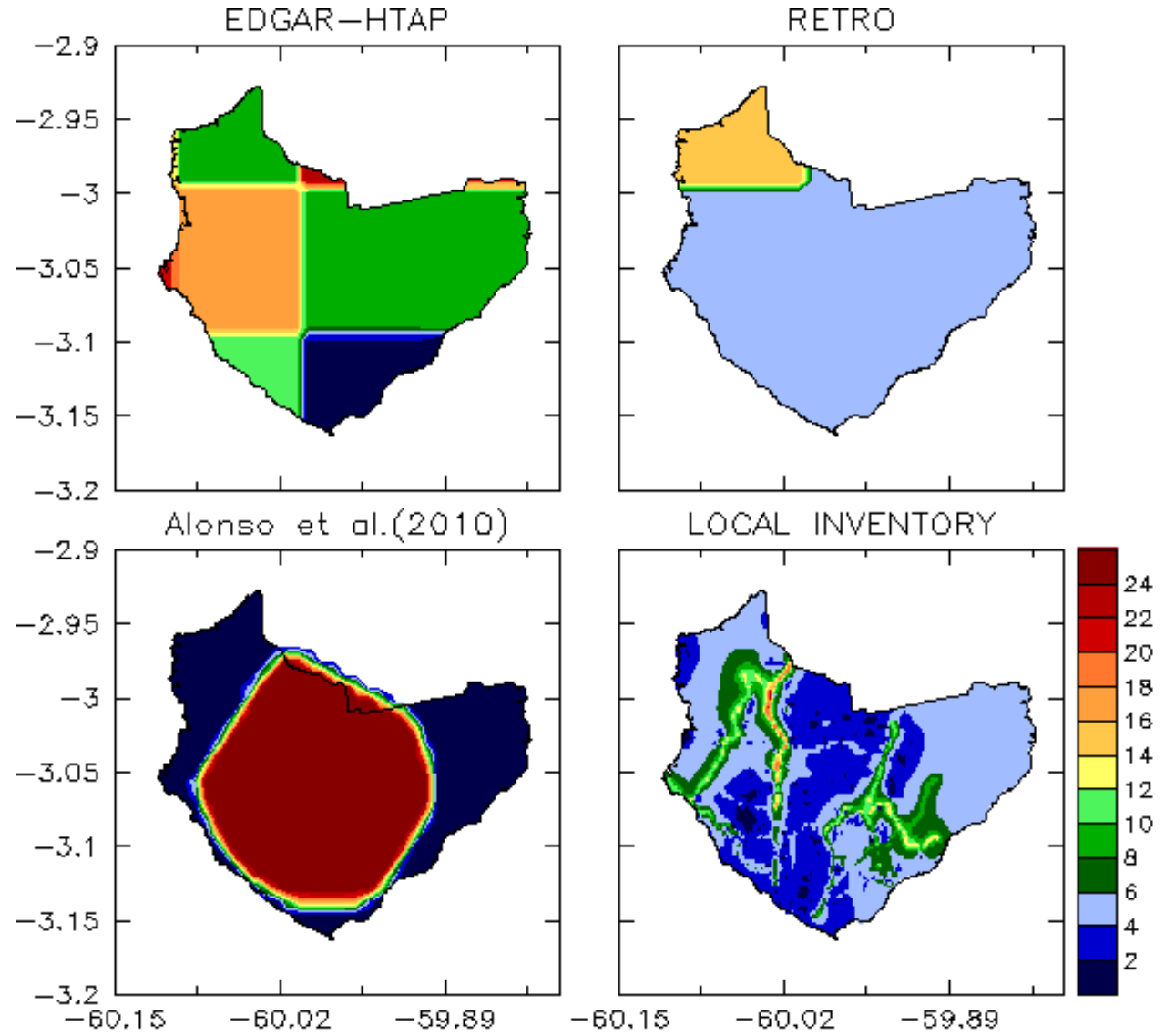

Figure 5. Spatial distribution of CO $\left(10^{-6} \mathrm{~kg} \mathrm{~m}^{-2}\right.$ day $\left.^{-1}\right)$ at Manaus urban area. 